\title{
Positive effect of BSA supplemented soybean lecithin based extender on liquid storage of ram semen at $5^{\circ} \mathrm{C}$
}

\author{
Elif GÖKÇE ${ }^{1}$, Selim ALÇAY', Zülfiye GÜL ${ }^{2}$ \\ Uludağ University, Faculty of Veterinary Medicine, ${ }^{1}$ Department of Reproduction and Artificial Insemination; ${ }^{2}$ Department of \\ Pharmacology, Bursa, Turkey.
}

\begin{abstract}
Summary: The aim of the study was to evaluate different BSA doses in soybean-lecithin based extenders for liquid storage of ram semen. Pooled semen was divided into four equal volumes and diluted in a single-step dilution method with BSA supplemented (BSA5, BSA7.5, BSA10 groups supplemented $5 \mathrm{mg} / \mathrm{mL}, 7.5 \mathrm{mg} / \mathrm{mL}, 10 \mathrm{mg} / \mathrm{mL}$ BSA respectively) and BSA-free (control) extenders. Semen samples were assessed for sperm motility, plasma membrane functional integrity using hypo-osmotic swelling test (HOST), damaged acrosome using FITC-Pisum sativum agglutinin (PSA-FITC) at 0,24, 48 and $72 \mathrm{~h}$ of storage at $5{ }^{\circ} \mathrm{C}$. Antioxidant activities of groups at 0 and $72 \mathrm{~h}$ were measured with glutathionine (GSH) concentration, membrane lipid peroxidation status was analyzed using the malondialdehyde (MDA) concentration. Antioxidant capacity of extender also was measured with 2,2-Diphenyl-1-picrylhydrazyl (DPPH) and Dichloro-dihydro-fluorescein diacetate (DCFH-DA) assays. In the study, BSA $(5 \mathrm{mg} / \mathrm{mL})$ supplementation has beneficial effect on ram sperm parameters at all evaluation times. In addition, the increasing doses of BSA supplementation has a negative effect on sperm parameters especially 48 and $72 \mathrm{~h}$ of storage.
\end{abstract}

Keywords: BSA, lecithin, ram semen, short-term storage.

\section{BSA ilave edilmiş lesitin bazlı sulandırıcının koç spermasının $5^{\circ} \mathrm{C}$ sıcaklıkta muhafaza edilmesine olumlu etkisi}

\begin{abstract}
Özet: Bu çalışmada, farklı dozlarda BSA ilave edilmiş lesitin bazlı sulandırıcının koç spermasının $5^{\circ} \mathrm{C}$ 'ta kısa sureli saklanması üzerindeki etkisinin değerlendirilmesi amaçlandı. Çalışma amacıyla alınan spermalar pooling yapılarak dört eşit hacme bölündü ve $5 \mathrm{mg} / \mathrm{mL}, 7.5 \mathrm{mg} / \mathrm{mL}, 10 \mathrm{mg} / \mathrm{mL}$ BSA ilave edilmiş (BSA5, BSA7.5, BSA10 sırasıyla) ve edilmemiş (kontrol) sulandırıcılarla sulandırıldı. Sulandırılmış spermanın sıcaklığ $15^{\circ} \mathrm{C}$ 'a düştükten sonra $0,24,48$ ve 72 . saatlerde; motilite, plazma membran fonksiyonel bütünük [hipoozmotik şişme testi (HOST)] ve akrozomal hasar [FITC-Pisum sativum agglutinin (PSA-FITC)] muayeneleri yapıldı. Çalışmanın başlangıcı ve sonunda antioksidan aktivitenin ve lipid peroksidasyonun değerlendirilmesi için malondialdehyde (MDA) ve glutathionine (GSH) konsantrasyonları ölçüldü. Ayrıca 2,2-Diphenyl-1-picrylhydrazyl (DPPH) ve Dichloro-dihydro-fluorescein diacetate (DCFH-DA) yöntemleri ile her bir sulandırıcının antioksidan kapasiteleri değerlendirildi. Yapılan muayenelerin sonucunda; $5 \mathrm{mg} / \mathrm{mL}$ BSA ilavesinin koç spermasının kısa süreli muhafazasında etkili olduğu gözlemlendi. Ayrıca artan BSA konsantrasyonunun spermanın soğutularak saklanmasında olumsuz etki oluşturduğu belirlendi.

Anahtar sözcükler: BSA, kısa süreli muhafaza, koç sperması, lesitin.
\end{abstract}

\section{Introduction}

Artificial insemination (AI) with preserved semen is one of the most common reproductive techniques for production of domestic animals. Semen preservation requires a depression or interruption of spermatozoa metabolism which is performed by cryopreservation or liquid storage (29). Ram sperm is more sensitive to cryopreservation than those of other mammalian species because of the polyunsaturated phospholipid membrane structure (5). Liquid storage can be an alternative to cryopreservation of ram semen to avoid detrimental effects of freezing-thawing processes for short time preservation (29). Despite all its advantages, liquid storage, which means keeping the temperature low to extend the survivability of spermatozoa, causes reversible and irreversible decreases on motility, viability and fertility of spermatozoa. Irreversible reduction of spermatozoa metabolism originates from cold shock, lipid peroxidation (29) and also incomplete cessation of metabolism during liquid storage (29). However reversible reduction of spermatozoa metabolism, an indicator of successful liquid storage, depends on providing the effective environmental conditions (e.g. suitable extender) to spermatozoa during liquid storage (14). Optimal semen extender must protect spermatozoa against the detrimental effects of cold shock and lipid peroxidation. 
Providing protection against the cold shock, egg yolk is one of the most common ingredients of semen extenders $(29,38)$. The non-dialyzable protein fractions and low density lipoproteins (lecithin) of egg yolk provide the best protection to ram semen during liquid storage (38). Egg yolk contributes to protection from the detrimental effects of cold shock through maintenance of the motility, plasma membrane and acrosome integrity during cryopreservation (38) and liquid storage (16) of ram spermatozoa. On the other hand, main disadvantages of using an animal-derived material in semen extender can be listed as: failure to prevent individual differences (lack of homogeneity), risk of contamination and transmission of diseases $(16,38)$. The low-density lipoprotein fraction such as lecithin $(35,38)$ or multifunctional macromolecules such as bovine serum albumin (BSA) $(19,31,33)$ could be substitutes for egg yolk in a semen extender.

Lipid peroxidation and its final product Reactive Oxygen Species (ROS) are other limiting factors in semen preservation $(1,3,27)$. Their depredatory effects can be specified as irreversible reduction on motility and viability of spermatozoa, and moreover, permanent damages on plasma membrane, acrosome and DNA $(11,12)$. On natural conditions, antioxidant system elements of spermatozoa and seminal plasma protect the spermatozoa against the lipid peroxidation (3). However, this antioxidant activity is insufficient when lipid peroxidation is originating from artificial conditions as liquid storage. Therefore, exogenous antioxidant supplementation is required for ram semen preservation to improve the fertility (29). In recent years, various antioxidants have been used for semen preservation by several researchers $(11,13,35)$.

Among the wide range of antioxidant species, BSA attracts the attention because of its multifunctional effects on spermatozoa. It is known that, in addition to antioxidant capacity, BSA accelerates the motility $(36,37)$, protects the membrane (36) and DNA integrity (33), increases the survivability of spermatozoa, and induces the capacitation (40) and acrosome reaction (26). As a consequence of these, BSA supplemented extenders are used for cryopreservation or liquid storage of bull (37), ram (35), goat $(6,7)$, stallion (9), buffalo (2), rabbit (34) and turkey (8) semen.

Although lecithin and BSA supplementation was used as an alternative to egg yolk through improving the preservation conditions of semen extenders $(35,38)$, there are no researches about the efficiency of lecithin-BSA combination for liquid storage of ram semen. The objective of this study was to find out the optimum dose of BSA in lecithin based extenders for improving the motility, viability and acrosome integrity of ram spermatozoa at $5{ }^{\circ} \mathrm{C}$ during storage for $72 \mathrm{~h}$.

\section{Materials and Methods}

All issues concerning the experimental setups and evaluation techniques have been approved by Uludağ University Scientific Ethical Committee (No: 201507/03).

Experimental design: We designed this study to evaluate the efficacy of BSA supplementation for liquid storage of ram semen. For this purpose, we used 1\% lecithin based extender with 3 concentrations of BSA (5, $7.5,10 \mathrm{mg} / \mathrm{mL}$ ) and without BSA supplementation (control) for short term storage, and then assessed the lifespan and spermatological parameters of liquid stored ram semen at 4 times $(0,24,48,72 \mathrm{~h}) . \quad$ Semen extender preparation: Experimental groups were designed according to the amount of BSA supplementation such as BSA5 (with $5 \mathrm{mg} / \mathrm{mL}$ BSA), BSA7.5 (with $7.5 \mathrm{mg} / \mathrm{mL}$ BSA), BSA10 (with $10 \mathrm{mg} / \mathrm{mL}$ BSA) and Control (without BSA). Extenders consisted of $223.7 \mathrm{mmol} / \mathrm{L}$ Tris (Sigma, USA), $55.5 \mathrm{mmol} / \mathrm{L}$ fructose (Sigma), 66.6 mmol/L citric acid (Merck, Darmstadt, Germany), 100.4 $\mathrm{mmol} / \mathrm{L}$ Trehalose, $4.03 \mathrm{mmol} / \mathrm{L}$ EDTA, $1 \mathrm{mmol} / \mathrm{L}$ cysteine, $4 \mathrm{~g} / \mathrm{L}$ penicillin $\mathrm{G}, 3 \mathrm{~g} / \mathrm{L}$ dihydrostreptomycin, $1 \%$ lecithin in distilled water.

Semen collection and dilution: Five Kivircik rams aged between 3-5 years were used as the material of study during non-breeding season. Rams were maintained at Uludağ University, Faculty of Veterinary Medicine in Bursa, Turkey. Electrically stimulated ejaculatior (Ruakura Ram Probe Plastic Products, Hamilton, New Zealand) was used for semen collection five times in every other day. After collection, the ejaculates were transferred to andrology laboratory in a water bath $\left(32^{\circ} \mathrm{C}\right)$ and then evaluated for rapid wave motion and subjective motility via a phase-contrast microscope (Olympus BX51, Olympus Optical Co., Tokyo, Japan) with a warm slide $\left(38^{\circ} \mathrm{C}\right)$. Only ejaculates with rapid wave $(>+3$ on $0-5$ scale), $>75 \%$ motility and at least $1 \times 10^{9}$ spermatozoa $/ \mathrm{mL}$ were used for liquid storage. To eliminate individual differences, chosen ejaculates were pooled and split into four equal aliquots. Each group was separately diluted to final concentration of approximately $500 \times 10^{6}(\mathrm{spz} / \mathrm{mL})$ with control (without BSA) or BSA supplemented extenders (containing 5, 7.5, and $10 \mathrm{mg} / \mathrm{mL}$ BSA, respectively) then cooled to $5{ }^{\circ} \mathrm{C}$ within $60 \mathrm{~min}$. Cooled samples were maintained at $5{ }^{\circ} \mathrm{C}$ during $72 \mathrm{~h}$. Five pooled ejaculates were included in the study.

Semen evaluation: We assessed sperm motility, plasma membrane integrity (hypo-osmotic swelling test [HOST]) and acrosome integrity (FITC conjugated Pisum_sativum agglutinin [FITC PSA]) four times (0, 24, 48 and $72 \mathrm{~h}$ of liquid storage at $5{ }^{\circ} \mathrm{C}$ ). Also MDA and GSH concentrations were measured at 0 and $72 \mathrm{~h}$ of storage at $5{ }^{\circ} \mathrm{C}$. To eliminate personal differences; all processes were performed by same person during the study. 
Fluorescein lectin staining assay (FITC conjugated Pisum sativum agglutinin [FITC PSA]): PSA-FITC staining performed for assessment of acrosome integrity. We performed this staining according to description of Alçay et al. 2014 with a fluorescence microscope (Olympus BX51) (4). At least 200 spermatozoa per smear were evaluated for acrosome integrity.

The hypo-osmotic swelling test (HOST): Sperm membrane functional integrity was evaluated by the hypoosmotic swelling test. This evaluation was based upon concentration of spermatozoa which have curled and swollen tails. Semen samples $(10 \mu \mathrm{L})$ were separately incubated with $100 \mu \mathrm{l}$ of a $100 \mathrm{~m}$ OsM hypo-osmotic solutions (5) at $37^{\circ} \mathrm{C}$ for $60 \mathrm{~min}$. After incubation, mixture was dropped on a microscope slide and covered with coverslip. At least 200 spermatozoa were evaluated with phase-contrast microscope (Olympus BX51) with a warm slide $\left(38{ }^{\circ} \mathrm{C}\right)$ and sperms that have swollen or coiled tails were counted (5).

Determination of oxidative stress markers: The MDA levels of each group were measured according to the thiobarbituric acid method (3, 35). For this purpose, thiobarbituric acid solution (0.67\%) was added to supernatant in a glass tube with 2:1 volume and then tubes were hold at $100{ }^{\circ} \mathrm{C}$ for $60 \mathrm{~min}$. After cooling the tubes, the absorbance of the supernatant was read at $546 \mathrm{~nm}$ via spectrophotometer (Mannheim Boehringer Photometer 4010). The results were expressed as $\mathrm{nmol} / \mathrm{mL}$. MDA standard of this evaluation is 1,1,3,3-tetramethoxypropane.

For measuring the GSH levels Ellman method was followed (20). $2 \mathrm{~mL}$ of $\mathrm{Na}_{2} \mathrm{HPO}_{4} 2 \mathrm{H}_{2} \mathrm{O}(0.3 \mathrm{M})$ and $0.2 \mathrm{~mL}$ of 5.5 -dithiobis-2-nitrobenzoic acid $(0.4 \mathrm{mg} / \mathrm{mL}$ in $1 \%$ sodium citrate) were mixed with $0.5 \mathrm{~mL}$ of the supernatant. After vortexing, the absorbance was read with spectrophotometer (Mannheim Boehringer Photometer $4010)$ at $405 \mathrm{~nm}$. The results were expressed as $\mu \mathrm{mol} / \mathrm{mg}$ protein.

Evaluation of antioxidant capacity of extender: Antioxidant activity of extender was investigated by using DPPH (2,2-Diphenyl-1-picrylhydrazyl) and Dichlorodihydro-fluorescein diacetate (DCFH-DA) assays.

DPPH evaluation was performed according to Dorman method and the results were given as \% of inhibition (18). $450 \mu \mathrm{L}$ of Tris- $\mathrm{HCl}$ buffer $(50 \mathrm{mM})$ was premixed with $1.0 \mathrm{~mL}$ of DPPH $(0.1 \mathrm{mM}$, in methanol) then $50 \mu \mathrm{L}$ of seminal plasma was added to premixed solution. Final solution was incubated in darkness and room temperature during 30 minutes. The resultant absorbance was recorded at $517 \mathrm{~nm}$. The percentage inhibition was calculated using the following equation;

Inhibition $(\%)=[$ Absorbance of controlAbsorbance of sample) / Absorbance of control] $\times 100$

DCFH-DA assay depend on measurement of $\mathrm{H}_{2} \mathrm{O}_{2}$ Induced fluorescence in incubation medium. For the first stage, increasing concentrations of $\mathrm{H} 2 \mathrm{O} 2$ were incubated in $2 \mathrm{~mL}$ of oxygenated medium and $2 \mathrm{~mL}$ of DCFH-DA oxygenated medium mixture $(5 \mu \mathrm{M})$ for $1 \mathrm{~h}$ at $37^{\circ} \mathrm{C}$ in the dark. For the second phase, extenders (control, BSA5, BSA7.5 and BSA10) were incubated with $2 \mathrm{~mL}$ of oxygenated physiological medium $(\mathrm{pH} 7.5)$ for $1 \mathrm{~h}$ at $37^{\circ} \mathrm{C}$ in the dark. After the incubation process, $200 \mu \mathrm{L}$ of the aliquots was diluted with $2 \mathrm{~mL}$ of distilled water. Measurement of fluorescence intensities was performed as indicated above. For assessment of fluorescence intensities in control conditions, $2 \mathrm{~mL}$ of distilled water was incubated with oxygenated physiological medium and it was exposed to same processes.

Statistical analysis: All data obtained from study were analyzed using SPSS (SPSS 20.0 for Windows; SPSS, Chicago, IL, USA). Data were represented as mean \pm standard error. Shapiro Wilk test was used as normality test. Means of obtained semen parameters were analyzed using Kruskal Wallis test followed by Mann Whitney U test. Paired samples were analyzed using Wilcoxon Signed Ranks test.

\section{Results}

The effects of different doses on semen parameters through liquid storage processes was evaluated in 5 experiments. Table 1 and Table 2 show the percentages of sperm motility, plasma membrane functional integrity and acrosome integrity of study groups at $0 \mathrm{~h}$ (time point of solution temperature reaches $\left.5^{\circ} \mathrm{C}\right), 24 \mathrm{~h}, 48 \mathrm{~h}$, and $72 \mathrm{~h}$. Figure 1 and Figure 2 show the MDA and GSH concentration of 0 and $72 \mathrm{~h}$ preservation at $5{ }^{\circ} \mathrm{C}$.

Motility: The liquid storage process significantly reduced sperm motility. Effect of extenders on sperm motility is shown in Figure 3. The motility values of BSA5 group, except at $0 \mathrm{~h}$, were higher than the control group through the study $(\mathrm{p}<0.05)$. At the end of $72 \mathrm{~h}$ liquid storage, BSA5 group had higher motility rate than the other groups $(\mathrm{p}<0.05)$. The increasing doses of BSA had a negative impact on motility at 48 and $72 \mathrm{~h}$ compared to the BSA5 group.

Plasma membrane integrity: Plasma membrane functional integrity decreased during liquid storage process. It is observed that, BSA supplementation helped to protection of membrane integrity successfully compared with the control group up to $48 \mathrm{~h}$ of liquid storage $(\mathrm{p}<0.05)$. After $72 \mathrm{~h}$ storage, BSA5 group had a higher HOST value than the other groups $(\mathrm{p}<0.05)$.

Acrosomal status: Acrosome integrity deteriorated during preservation process $(\mathrm{p}<0.05)$. However, BSA5 group provided the best protection. Increasing doses of BSA caused reduction of acrosomal integrity.

Oxidative stress markers: Figure 1 and Figure 2 show the effect of MDA and GSH levels (respectively) at 
$0 \mathrm{~h}$ and $72 \mathrm{~h}$ of liquid storage. In respect to MDA levels, control group was significantly higher than BSA groups although there were no significant differences among BSA groups at 0 and $72 \mathrm{~h}$. GSH levels of all experiment groups were similar both starting and finishing of liquid storage $(\mathrm{p}>0.05)$.

Table 1. Mean values $(\overline{\mathrm{x}} \pm \mathrm{S} \overline{\mathrm{x}})$ of sperm parameters for extender groups at $0 \mathrm{~h}$ and $24 \mathrm{~h}(\mathrm{n}=5)$.

Tablo 1.0 ve 24. saatlerdeki spermatolojik parametrelerin ortalama \pm standart hata $(\overline{\mathrm{x}} \pm \mathrm{S} \overline{\mathrm{x}})$ değerleri $(\mathrm{n}=5)$.

\begin{tabular}{llll|lll}
\hline \multirow{2}{*}{ GROUP } & $0 \mathrm{~h}$ & & $24 \mathrm{~h}$ & \\
\cline { 2 - 7 } & $\begin{array}{l}\text { MOTILITY } \\
(\overline{\mathrm{x}} \pm \mathrm{S} \overline{\mathrm{x}})\end{array}$ & $\begin{array}{l}\text { HOST POSITIVE } \\
(\overline{\mathrm{x}} \pm \mathrm{S} \overline{\mathrm{x}})\end{array}$ & $\begin{array}{l}\text { PSA POSITIVE } \\
(\overline{\mathrm{x}} \pm \mathrm{S} \overline{\mathrm{x}})\end{array}$ & $\begin{array}{l}\text { MOTILITY } \\
(\overline{\mathrm{x}} \pm \mathrm{S} \overline{\mathrm{x}})\end{array}$ & $\begin{array}{l}\text { HOST POSITIVE } \\
(\overline{\mathrm{x}} \pm \mathrm{S} \overline{\mathrm{x}})\end{array}$ & $\begin{array}{l}\text { PSA POSITIVE } \\
(\overline{\mathrm{x}} \pm \mathrm{S} \overline{\mathrm{x}})\end{array}$ \\
\hline Control & $66.00 \pm 1.00^{\mathrm{a}}$ & $73.20 \pm 1.53^{\mathrm{a}}$ & $75.20 \pm 2.63^{\mathrm{a}}$ & $61.00 \pm 1.00^{\mathrm{a}}$ & $64.00 \pm 1.95^{\mathrm{a}}$ & $60.40 \pm 2.32^{\mathrm{a}}$ \\
BSA5 & $71.25 \pm 3.15^{\mathrm{a}}$ & $81.50 \pm 2.60^{\mathrm{b}}$ & $86.75 \pm 0.85^{\mathrm{b}}$ & $68.75 \pm 2.39^{\mathrm{b}}$ & $71.25 \pm 3.35^{\mathrm{a}}$ & $71.5 \pm 1.85^{\mathrm{b}}$ \\
BSA7.5 & $67.00 \pm 1.22^{\mathrm{a}}$ & $78.20 \pm 1.28^{\mathrm{ab}}$ & $82.60 \pm 1.54^{\mathrm{b}}$ & $63.00 \pm 1.22^{\mathrm{ab}}$ & $68.20 \pm 1.64^{\mathrm{a}}$ & $68.00 \pm 2.90^{\mathrm{ab}}$ \\
BSA 10 & $68.00 \pm 1.22^{\mathrm{a}}$ & $79.60 \pm 1.47^{\mathrm{ab}}$ & $81.80 \pm 1.07^{\mathrm{ab}}$ & $61.00 \pm 1.87^{\mathrm{ab}}$ & $67.60 \pm 2.78^{\mathrm{a}}$ & $65.20 \pm 2.96^{\mathrm{ab}}$ \\
\hline
\end{tabular}

$a$ and $b$ : Values with different superscripts in the same column for each of storage time are significantly different $(p<0.05)$.

a and b: Her muhafaza saati için aynı sütunda farklı harfleri taşıyan sulandırıcı ortalamaları arasında istatistiksel olarak fark vardır $(\mathrm{p}<0.05)$.

Table 2. Mean values $(\overline{\mathrm{x}} \pm S \overline{\mathrm{x}})$ of studied sperm parameters for extender groups at $48 \mathrm{~h}$ and $72 \mathrm{~h}(\mathrm{n}=5)$.

Tablo 2. Çalışmanın 48 ve 72. saatlerdeki spermatolojik parametrelerin ortalama \pm standart hata $(\bar{x} \pm S \bar{x})$ değerleri $(n=5)$.

\begin{tabular}{llll|lll}
\hline \multirow{2}{*}{ GROUP } & $48 \mathrm{~h}$ & $72 \mathrm{~h}$ & \\
\cline { 2 - 7 } & $\begin{array}{l}\text { MOTILITY } \\
(\overline{\mathrm{x}} \pm \mathrm{S} \overline{\mathrm{x}})\end{array}$ & $\begin{array}{l}\text { HOST POSITIVE } \\
(\overline{\mathrm{x}} \pm \mathrm{S} \overline{\mathrm{x}})\end{array}$ & $\begin{array}{l}\text { PSA POSITIVE } \\
(\overline{\mathrm{x}} \pm \mathrm{S} \overline{\mathrm{x}})\end{array}$ & $\begin{array}{l}\text { MOTILITY } \\
(\overline{\mathrm{x}} \pm \mathrm{S} \overline{\mathrm{x}})\end{array}$ & $\begin{array}{l}\text { HOST POSITIVE } \\
(\overline{\mathrm{x}} \pm \mathrm{S} \overline{\mathrm{x}})\end{array}$ & $\begin{array}{l}\text { PSA POSITIVE } \\
(\overline{\mathrm{x}} \pm \mathrm{S} \overline{\mathrm{x}})\end{array}$ \\
\hline Control & $53.00 \pm 2.55^{\mathrm{ab}}$ & $57.60 \pm 0.60^{\mathrm{a}}$ & $47.00 \pm 1.00^{\mathrm{a}}$ & $38.00 \pm 2.55^{\mathrm{a}}$ & $43.80 \pm 1.32^{\mathrm{a}}$ & $40.80 \pm 1.50^{\mathrm{a}}$ \\
BSA5 & $61.25 \pm 3.15^{\mathrm{a}}$ & $67.50 \pm 2.53^{\mathrm{b}}$ & $61.50 \pm 2.50^{\mathrm{b}}$ & $50.00 \pm 2.04^{\mathrm{b}}$ & $56.00 \pm 2.48^{\mathrm{b}}$ & $56.00 \pm 2.16^{\mathrm{b}}$ \\
BSA7.5 & $53.00 \pm 2.55^{\mathrm{ab}}$ & $59.00 \pm 1.70^{\mathrm{ab}}$ & $54.40 \pm 2.80^{\mathrm{ab}}$ & $37.00 \pm 2.00^{\mathrm{a}}$ & $47.00 \pm 0.95^{\mathrm{a}}$ & $49.20 \pm 1.56^{\mathrm{bc}}$ \\
BSA 10 & $46.00 \pm 2.92^{\mathrm{b}}$ & $52.60 \pm 2.77^{\mathrm{a}}$ & $49.20 \pm 2.22^{\mathrm{a}}$ & $35.00 \pm 2.24^{\mathrm{a}}$ & $43.20 \pm 1.62^{\mathrm{a}}$ & $43.20 \pm 2.18^{\mathrm{ac}}$ \\
\hline
\end{tabular}

$a, b$ and $c$ : Values with different superscripts in the same column for each of storage time are significantly different $(p<0.05)$.

a,b ve c: Her muhafaza saati için aynı sütunda farklı harfleri taşıyan sulandırıcı ortalamaları arasında istatistiksel olarak fark vardır $(\mathrm{p}<0.05)$.

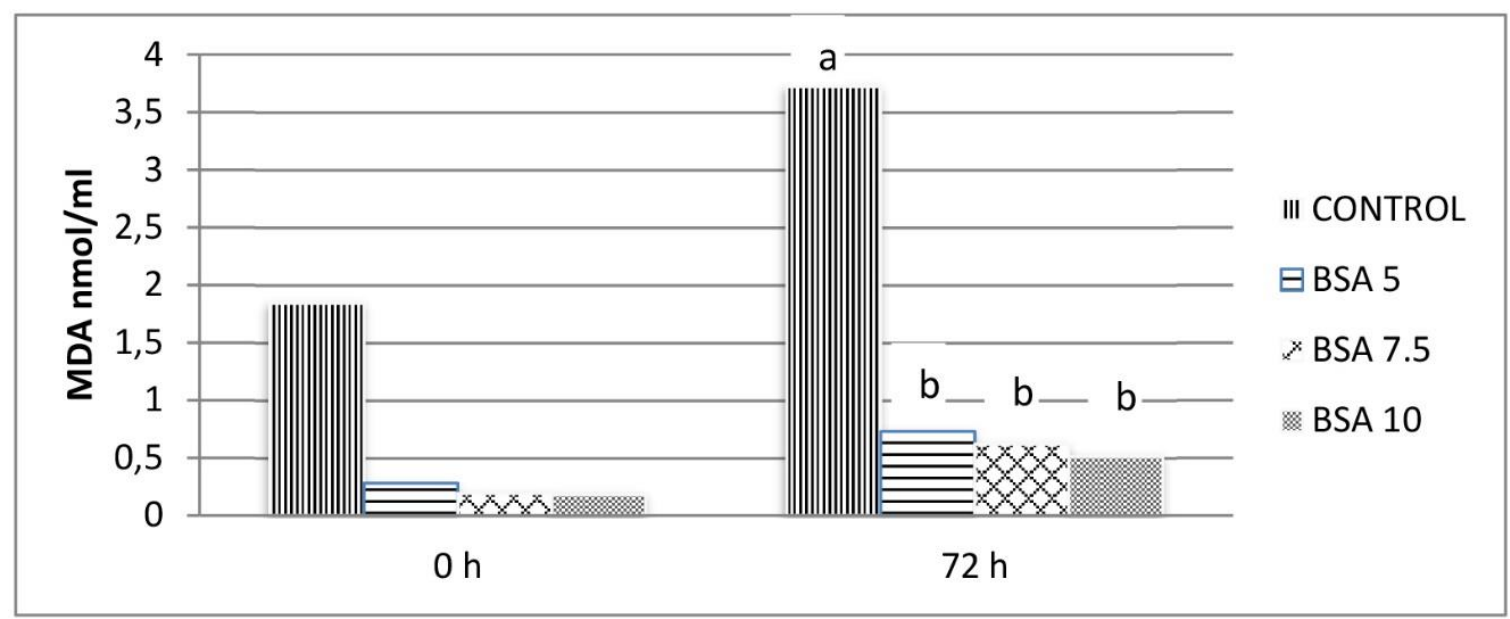

Figure 1. MDA levels at the beginning and finishing of liquid storage. There are no differences among the groups at $0 \mathrm{~h}(\mathrm{P}>0.05)$. $\mathrm{a}$ and $\mathrm{b}$ : Values with different superscripts at the same storage time are significantly different $(\mathrm{P}<0.05)$.

Şekil 1. Kısa süreli saklamanın başlangıç ve bitiş zamanlarına ait MDA değerleri. Gruplar arasında 0. saat MDA değerleri bakımından fark yoktur $(\mathrm{P}>0.05)$.

a ve b: Farklı harfleri taşıyan sulandırıcı ortalamaları arasında istatistiksel olarak fark vardır $(\mathrm{P}<0.05)$. 
Table 3. Mean values $(\overline{\mathrm{x}} \pm \mathrm{S} \overline{\mathrm{x}})$ of antioxidant capacity of extenders.

Tablo 3. Kullanılan sulandırıcı gruplarına ait ortalama \pm standart hata $(\overline{\mathrm{x}} \pm \mathrm{S} \overline{\mathrm{x}})$ antioksidatif kapasite değerleri.

\begin{tabular}{l|l|l|l|l} 
& CONTROL & BSA5 & BSA7.5 & BSA10 \\
\hline $\begin{array}{l}\text { DFCH-DA } \\
\text { Inhibiton flourence intensity \%) }\end{array}$ & $78.20 \pm 1.1^{\mathrm{a}}$ & $79.01 \pm 1.4^{\mathrm{a}}$ & $76.46 \pm 1.4^{\mathrm{a}}$ & $73.28 \pm 2.9^{\mathrm{b}}$ \\
\hline Inhibition DPPH Activity (\%) & $40.00 \pm 3.2^{\mathrm{a}}$ & $60.00 \pm 5.4^{\mathrm{b}}$ & $53.00 \pm 6.3^{\mathrm{c}}$ & $49.00 \pm 2.1^{\mathrm{c}}$ \\
\hline
\end{tabular}

a,b and c: Values with different superscripts in the same rows for each experiment method are significantly different $(p<0.05)$. a,b ve c: Her değerlendirme yöntemi için aynı satırdaki farklı harfleri taşıyan sulandırıcı ortalamaları arasında istatistiksel olarak fark vardır $(\mathrm{p}<0.05)$.

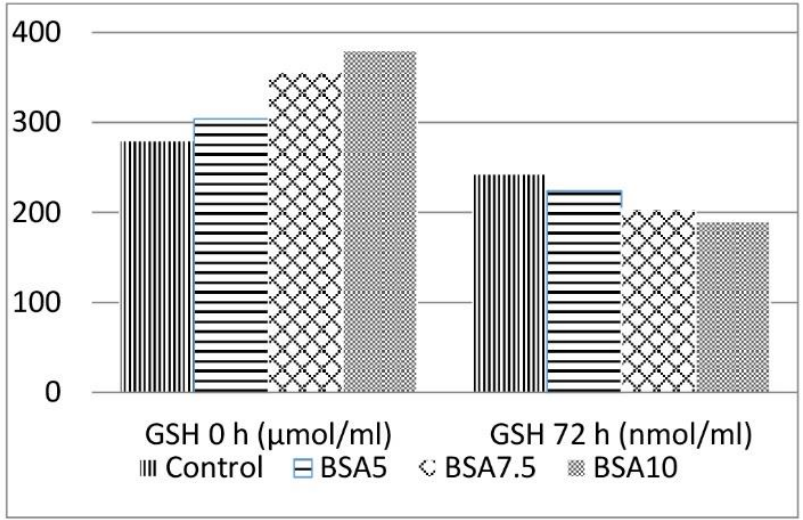

Figure 2. GSH levels at the starting and ending of liquid storage. There are no differences among the groups at certain times $(\mathrm{P}>0.05)$.

Şekil 2. Kısa süreli saklamanın başlangıç ve bitiş zamanlarına ait GSH değerleri. Belirtilen saatlerde (0. saat, 72. saat) gruplar.

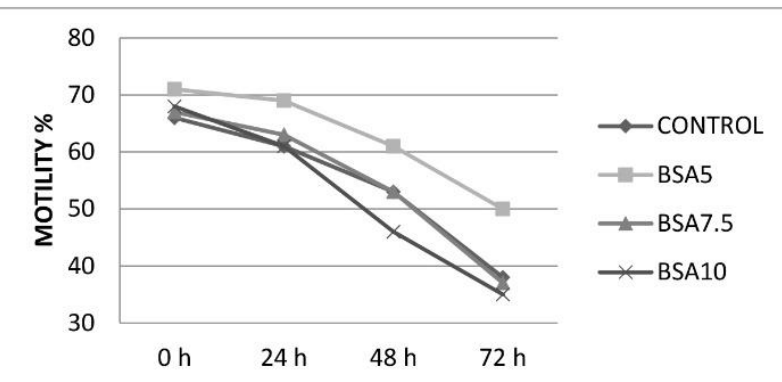

Figure 3. Effects of BSA in semen extender on motility at different evaluation times.

Şekil 3. BSA ilave edilmesinin farklı değerlendirme saatlerinde motilite üzerine etkisi.

Antioxidant capacity of extender: Table 3 shows the antioxidant capacity of extenders. According to DCFHDA analyses; inhibition florescence intensity $\%$ of control, BSA5, BSA7.5, BSA10 groups were $78.20 \pm 1.1 \%, 79.01$ $\pm 1.4 \%, 76.46 \pm 1.4 \%$ and $73.28 \pm 2.9 \%$ respectively. Florescence intensity of BSA10 group was lower than other groups $(\mathrm{p}<0.05)$.

Inhibition DPPH activity (\%) of control, BSA5, BSA7.5, BSA10 groups were $40 \pm 3.2 \%, 60 \pm 5.4 \%, 53 \pm$ $6.3 \%$ and $49 \pm 2.1 \%$ respectively. According to this results inhibition DPPH activity of BSA5 group was significantly higher than other groups. Also there were differences between control and other experiment groups $(p<0.05)$.

\section{Discussion and Conclusion}

Liquid storage is used as an alternative of ram semen cryopreservation for short-time storage because of detrimental effects of cryopreservation (29). However, continuing spermatozoa metabolism and cold shock cause some negative effects on spermatozoa with the passing of time (29).

BSA was tested as a semen extender ingredient by several researchers because of its stability, good amino acid profile and protective functions $(28,36,37)$. In the present study we compared $1 \%$ lecithin based extender containing different doses of BSA $(5 \mathrm{mg} / \mathrm{mL}, 7.5 \mathrm{mg} / \mathrm{mL}$, $10 \mathrm{mg} / \mathrm{mL}$ ) during liquid storage of ram semen in nonbreeding season. The results of the present study indicated a clear advantage of using $5 \mathrm{mg} / \mathrm{mL}$ of BSA in $1 \%$ lecithin based extender.

Motility of spermatozoa is the essential factor for sperm evaluation. It indicates the ability of passage through cervix and penetration of zona pellucida (3). Many researchers indicated that BSA stimulates sperm motility $(28,36,37)$ by an unknown mechanism $(36,37)$. In our study there were no differences among the groups at $0 \mathrm{~h}$, BSA supplementation increased the motility at 24 h. BSA10 group significantly reduced the motility of sperm compared to the BSA5 group at $48 \mathrm{~h}$ and $72 \mathrm{~h}$. Our results show that increasing doses of BSA have a negative effect on sperm motility. Although these results are inconsistent with certain researches $(19,28)$, this inconsistency could be originated from using different animal species and preservation methods. At the end of 72 $\mathrm{h}$, motility value of BSA5 group was significantly higher than other groups and this motility level (56\%) is appropriate for AI. Motility values of liquid stored ram semen ranged between $70 \%-84 \%, 60 \%-80 \%, 40 \%$ $78 \%, 30 \%-77 \%(0,24,48$ and $72 \mathrm{~h}$, respectively) in previous studies $(14,23,24,34)$. Despite our study performed in non-breeding season, results of our study were in agreement with these values.

Membrane damage of spermatozoa originates from cold shock, lipid peroxidation and ageing of spermatozoa during storage. Cold shock is probably related to phase separation and loss of selective permeability of spermatozoa which is dependent on phase transition of 
membrane lipids (29). BSA adheres to the sperm membrane and modifies the lipid composition of spermatozoa in several ways such as lipid exchange or hydrolysis of plasma membrane, protein hydrolysis, and decrease of cholesterol and phospholipid concentration of plasma membrane (15). It is known that increasing fluidity of plasma membrane decreases the susceptibility of spermatozoa against cold shock (19) therefore protective effects of BSA against cold shock depend on increasing membrane fluidity. Plasma membrane functional integrity is crucial for the evaluation of sperm quality, because it indicates the viability of spermatozoa (3). HOST has been used for detecting subtle changes in the functional integrity of sperm membranes (4). Acrosome integrity is another important factor in the fertilization process because it has been related with sperm penetration and fusion to zona pellicuda (5). Sarıözkan et al. (33) indicated that BSA protects the acrosomal integrity (33), and our results substantiated to that idea. As expected, plasma membrane and acrosome integrity of spermatozoa regularly decreased during liquid storage in our study $(p<0.05)$. However, we observed protective effects of BSA $(5 \mathrm{mg} / \mathrm{mL})$ on plasma membrane functional integrity and acrosome integrity. Plasma membrane and acrosome integrity values of BSA5 group had a good agreement with previous studies $(22,24)$.

MDA is often used as an indicator of oxidative damage. Therefore, it is a key product of lipid peroxidation in the cells $(3,35)$. GSH is a multifunctional non-protein which is known as a thiol group antioxidant in mammalian cells $(12,33,36)$. This compound counterattack the effects of oxidative stress in sperm cells directly and indirectly (throughout cooperation with GSHPX for reduction of toxic $\left.\mathrm{H}_{2} \mathrm{O}_{2}\right)(12,33,36)$. Therefore, it can be regarded as an indicator for antioxidant capacity of sperm cells. According to our results, BSA supplementation protect spermatozoa against lipid peroxidation. GSH values at 0 and $72 \mathrm{~h}$ were not significantly among the groups. This could be originated from our base extender include cysteine and this already have an antioxidant capacity. Our results agreed with previously published studies $(3,14,24)$

Demircan et al. (17) recently reported that incubating $\mathrm{H}_{2} \mathrm{O}_{2}$ and DCFH-DA in oxygenated physiological medium causes a significant increase in fluorescence intensity, and antioxidants can attenuate this increment. Thus, the effectiveness of antioxidant compounds against the $\mathrm{H}_{2} \mathrm{O}_{2}$-induced increase in fluorescence intensity was also tested in the medium. According to our results 10 $\mathrm{mg} / \mathrm{mL}$ BSA supplementation decreased the antioxidant capacity of semen extender compared to lower doses of BSA supplementation. Increasing values of \% inhibition DPPH activity is related with increasing antioxidant capacity. Our results showed that BSA5 group had a higher antioxidant capacity. Briefly, DFCH-DA and DPPH activities of extenders showed that increasing doses of BSA lose its antioxidant activity gradually. In current study, BSA started to pretend as an oxidant factor when the extender already has an antioxidant substance such as cysteine. Bouayed and Bohn (10) claimed that higher doses of isolated antioxidants, carve out pro-oxidant effect also cause cytotoxicity, DNA damage and apoptosis of cells (39). Also high concentrations of antioxidants can stimulate ROS production $(21,25,30,32)$ Negative effects of higher doses of BSA can be explained with these phenomena. Decrease of antioxidant performance could be the reason of decreasing motility, viability and integrity values of BSA10 groups and incompatibility results with previous research $(19,28)$.

In conclusion, results of the present study indicate that BSA $(5 \mathrm{mg} / \mathrm{mL})$ supplemented lecithin based extender preserved sperm motility, plasma membrane functional integrity, and acrosome integrity are better than both BSAfree and higher doses of BSA supplemented extenders when liquid ram semen was stored at $5{ }^{\circ} \mathrm{C}$ up to $72 \mathrm{~h}$. Beneficial effects of BSA supplementation on liquid storage of ram semen can be supported with fertility results after $\mathrm{AI}$ in future studies.

\section{Acknowledgements}

This work was supported by Uludağ University Scientific Research Projects Unit, Bursa, Turkey (BAP project number: KUAP (V)-2015/55).

\section{References}

1. Agarwal A, Makker K, Sharma R (2008): Clinical relevance of oxidative stress in male factor infertility: An update. J Reprod Immunol, 59, 2-11.

2. Akhter S, Rakha BA, Iqbal R, et al. (2014): Effect of bovine serum albumin on motility, plasmalemma, viability and chromatin integrity of buffalo bull spermatozoa and chromatin integrity of buffalo bull spermatozoa. Pakistan J Zool, 46, 115-120.

3. Alçay S, Gökçe E, Toker MB, et al. (2016): Freeze-dried egg yolk based extenders containing various antioxidants improve post-thawing quality and incubation resilience of goat spermatozoa. Cryobiology, 72, 269-273.

4. Alçay S, Toker MB, Üstüner B, et al. (2014): Investigation of relationships between DNA integrity and fresh semen parameters in rams. Kafkas Univ Vet Fak Derg, 20, 793798.

5. Alçay S, Toker MB, Gökçe E, et al. (2015): Successful ram semen cryopreservation with lyophilized egg yolk-based extender. Cryobiology, 71, 329-333.

6. Amidi F, Farshad A, Khor AK (2010): Effects of cholesterol-loaded cyclodextrin during freezing step of cryopreservation with TCGY extender containing bovine serum albumin on quality of goat spermatozoa. Cryobiology, 61, 94-99. 
7. Anghel A, Zamfirescu S, Dragomir C, et al. (2010): The effects of antioxidants on the cytological parameters of cryopreserved buck semen. Rom Biotech Lett, 15, 26-32.

8. Bakst MR, Cecil HC (1992): Effect of bovine serum albumin on motility and fecundity of turkey spermatozoa before and after storage. J Reprod Fert, 94, 287-293.

9. Ball BA, Medina V, Gravance CG, et al. (2001): Effect of antioxidants on preservation of motility, viability and acrosomal integrity of equine spermatozoa during storage at $5{ }^{\circ} \mathrm{C}$. Theriogenology, 56, 577-589.

10. Bouayed J, Bohn T (2010): Exogenous antioxidantsdouble-edged swords in cellular redox state health beneficial effects at physiologic doses versus deleterious effects at high doses. Oxid Med Cell Longev, 3, 228-237.

11. Bucak MN, Çoyan K, Öztürk C, et al. (2012): Methionine supplementation improves ram sperm parameters during liquid storage at $5{ }^{\circ} \mathrm{C}$. Cryobiology, 65, 335-337.

12. Bucak MN, Tekin N (2007): Protective effect of taurine, glutathione and trehalose on the liquid storage of ram semen. Small Rum Res, 73, 103-108.

13. Bucak MN, Tuncer PB, Sariözkan S, et al. (2009): Comparison of the effects of glutamine and an amino acid solution on post-thawed ram sperm parameters, lipid peroxidation and anti-oxidant activities. Small Rum Res, 81, 13-17.

14. Çoyan K, Başpınar N, Bucak MN, et al. (2010): Influence of methionine and dithioerythritol on sperm motility, lipid peroxidation and antioxidant capacities during liquid storage of ram semen. Res Vet Sci, 89, 426-431.

15. Davis BK, Byrne R, Hun B (1979): Studies on the mechanism of capacitation. II. Evidence for lipid transfer between plasma membrane of rat sperm and serum albumin during capacitation in vitro. Biochim Biophys Acta, 558, 257-266.

16. De Paz P, Esteso MC, Alvarez M, et al. (2010): Development of extender based on soybean lecithin for its application in liquid ram semen. Theriogenology, 74, 663671.

17. Demircan C, Gül Z, Büyükuysal RL (2014): High glutamate attenuates $S 100 B$ and $L D H$ outputs from rat cortical slices enhanced by either oxygen-glucose deprivation or menadione. Neurochem Res, 39, 1232-1244.

18. Dorman HJD, Peltoketo A, Hiltunen R, et al. (2003): Characterization of antioxidant properties of de-odourized aqueous extracts from selected Lamiaceae herbs. Food Chem, 83, 255-262.

19. El-Kon I (2011): Testing usability of bovine serum albumin (BSA) for preservation of Egyptian Buffalo semen. Am Eurasian J Agric Environ Sci, 11, 495-502.

20. Ellman GL (1959): Tissue sulfhydryl groups. Arch Biochem Biophys, 82, 70-77.

21. Gaspar J, Rodrigues A, Laires A, et al. (1994): On the mechanisms of genotoxicity and metabolism of quercetin. Mutagenesis, 9, 445-449.

22. Gündoğan M (2009): Short term preservation of ram semen with different extenders. Kafkas Univ Vet Fak Derg, 15, 429-435.

23. Gündoğan M, Tekerli M, Uçar M, et al. (2003): Effect of diluents on motility of ram sperm during storage at $5{ }^{\circ} \mathrm{C}$. Arch Androl, 49, 69-75.
24. Gündoğan M, Yeni D, Avdatek F, et al. (2010): Influence of sperm concentration on the motility, morphology, membrane and DNA integrity along with oxidative stress parameters of ram sperm during liquid storage. Anim Reprod Sci, 122, 200-207.

25. Hodnick WF, Kung FS, Roettger WJ, et al. (1986): Inhibition of mitochondrial respiration and production of toxic oxygen radicals by flavonoids. A structure-activity study. Biochem Pharmacol, 35, 2345-2357.

26. Hossain MS, Hyeong LJ, Miah AG, et al. (2007): Effect of fatty acids bound to bovine serum albumin- $V$ on acrosome reaction and utilization of glucose in boar spermatozoa. Reprod Med Biol, 6, 109-115.

27. Kankofer M, Kolm G, Aurich J (2005): Activity of glutathione peroxidase, superoxide dismutase and catalase and lipid peroxidation intensity in stallion semen during storage at $5{ }^{\circ} \mathrm{C}$. Theriogenology, 63, 1354-1365.

28. Matsuoka T, Imai H, Kohno H, et al. (2006): Effect of bovine serum albumin and trehalose in semen diluents for improvement of frozen-thawed ram semen. J Reprod Dev, 52, 675-683.

29. Maxwell WMC, Salamon S (1993): Liquid storage of ram semen: A review. Reprod Fertil Dev, 5, 613-638.

30. Metodiewa D, Jaiswal AK, Cenas N, et al. (1999): Quercetin may act as a cytotoxic prooxidant after its metabolic activation to semiquinone and quinoidal product. Free Radic Biol Med, 26,107-116.

31. Naijian HR, Kohram H, Zare SA, et al. (2013): Effects of various concentrations of BSA on microscopic and oxidative parameters of Mahabadi goat semen following the freeze-thaw process. Small Rum Res, 113, 371-375.

32. Ochiai M, Nagao M, Wakabayashi K, et al. (1984): Superoxide dismutase acts as an enhancing factor for quercetin mutagenesis in rat-liver cytosol by preventing its decomposition. Mutat Res, 129, 19-24.

33. Sarıözkan S, Tuncer PB, Bucak MN, et al. (2009): Influence of various antioxidants on microscopic-oxidative stress indicators and fertilizing ability of frozen-thawed bull semen. Acta Vet Brno, 78, 463-469.

34. Sarıözkan S, Türk G, Cantürk F, et al. (2013): The effect of bovine serum albumin and fetal calf serum on sperm quality, DNA fragmentation and lipid peroxidation of the liquid stored rabbit semen. Cryobiology, 67, 1-6.

35. Toker MB Alçay S, Gökçe E, et al. (2016): Cryopreservation of ram semen with antioxidant supplemented soybean lecithin-based extenders and impacts on incubation resilience. Cryobiology, 72, 205209.

36. Uysal O, Bucak MN (2007): Effect of oxidized serum albumin, cysteine and lycopene on the quality of frozen thawed ram semen. Acta Vet Brno, 76, 383-390.

37. Uysal O, Bucak MN, Yavaş İ, et al. (2007): Effect of various antioxidants on the quality of frozen-thawed bull semen. J Anim Vet Adv, 6, 1362-1366.

38. Üstüner B, Alçay S, Nur Z, et al. (2014): Effect of egg yolk and soybean lecithin on tris-based extender in post-thaw ram semen quality and in vitro fertility. Kafkas Univ Vet Fak Derg, 20, 393-398.

39. Watjen W, Michels G, Steffan B, et al. (2005): Low concentrations of flavonoids are protective in rat H4IIE 
cells whereas high concentrations cause DNA damage and apoptosis. J Nutr, 135, 525-531.

40. Xia J, Ren D (2009): The BSa-induced Ca(2+) influx during sperm capacitation is CATSPER channel-dependent. Reprod Biol Endocrinol, 7, 119-127.
Geliş tarihi: 30.05.2016 / Kabul tarihi: 06. 03.2017

\section{Address for correspondence:}

Elif GÖKÇE

Uludag University, Faculty of Veterinary Medicine,

Department of Reproduction and Artificial Insemination,

Bursa, Turkey.

e-mail:a.elif.gokce@gmail.com 